\title{
Obesitas Sebagai Faktor Prognosis Buruk pada Anak dengan Leukemia Limfoblastik Akut
}

\section{Giovanni Reynaldo', Bernadina Cynthia Carsantiningrum¹, Yurika Elizabeth Susanti²}

\author{
${ }^{1}$ RS St. Carolus, Jakarta, Indonesia \\ ${ }^{2}$ RS YPK Mandiri, Jakarta, Indonesia \\ Alamat Korespondensi: gioreynaldo@yahoo.com
}

\begin{abstract}
Abstrak
Tinjauan pustaka ini bertujuan untuk memberikan paparan mengenai faktor-faktor yang memengaruhi hasil akhir leukemia limfoblastik akut (LLA) pada anak. LLA merupakan jenis kanker yang paling umum terjadi pada anak dan merupakan penyebab kematian akibat kanker terbanyak pada usia di bawah 20 tahun. Salah satu masalah kronis yang perlu diperhatikan secara serius terutama dalam kasus LLA adalah obesitas. Beberapa mekanisme dianggap berperan dalam kaitan antara LLA dengan obesitas. Salah satunya adalah meningkatnya hormon endogen (hormon seks steroid, insulin dan insulin growth factor-1) akibat akumulasi lemak tubuh yang berperan penting dalam mengontrol pertumbuhan, diferensiasi, dan metabolisme sel. Inflamasi kronik juga berperan dalam timbulnya sel kanker. Sel adiposit merupakan sumber poten untuk timbulnya sitokin inflamasi. Prognosis buruk pada pasien anak dengan obesitas berkaitan dengan beberapa faktor seperti dosis terapi yang tidak adekuat, usia dibawah 1 tahun atau di atas 10 tahun pada saat diagnosis, dan hitung leukosit di atas 50.000/. $\mathrm{mm}^{3}$.
\end{abstract}

Kata kunci : anak, leukemia limfoblastik akut, leukositosis, obesitas, prognosis

\section{Obesity as A Poor Prognostic Factor of Pediatric Acute Lymphoblastic Leukemia}

\begin{abstract}
This literature review aims to describe the risk factors affecting outcomes in pediatric acute lymphoblastic leukemia (ALL). ALL is the most common cancer among children and the most frequent cause of death from cancer in the population aged below 20 years of age. Obesity is a chronic problem in children that needs to be taken seriously in ALL. Several mechanisms are considered to play a role in the correlation between ALL and obesity. These include increased endogenous hormones (sex steroid hormones, insulin, and insulin growth factor-1) due to the accumulation of body fat, which plays an important role in controlling cell growth, differentiation and metabolism. Chronic inflammation also plays a role in generating cancer cells. Adipocyte cells are a potent source of inflammatory cytokines. Poor prognosis of pediatric patients with obesity is related to factors such as inadequate therapeutic doses, patients diagnosed under 1 year of age or above 10 years of age, as well as leukocyte count of over $50,000 / \mathrm{mm}^{3}$.
\end{abstract}

Keywords : children, acute lymphoblastic leukemia, leukocytosis, obesity, prognosis 


\section{Pendahuluan}

Leukemia limfoblastik akut (LLA) merupakan kanker yang paling umum terjadi pada anak. ${ }^{1}$ Penyakit ini merupakan penyebab kematian akibat kanker terbanyak pada usia dibawah 20 tahun. ${ }^{1}$ LLA mewakili sekitar $25 \%$ diagnosis kanker pada anak, ${ }^{1}$ dan $75-80 \%$ dari leukemia akut pada anak. ${ }^{2}$ Insidens pada anak yaitu sekitar 3-4 kasus per 100.000 anak dibawah usia 15 tahun. ${ }^{2}$ Di Amerika Serikat, diperkirakan ada sekitar 30 kasus per 1.000.000 orang di bawah usia 20 tahun. ${ }^{1}$ Diperkirakan sekitar 6000 anak dan remaja didiagnosis LLA setiap tahun sebelum tahun 2015; angka ini angka ini diperkirakan naik terus. ${ }^{1}$ Pada waktu yang sama, obesitas pada anak semakin banyak ditemukan. Obesitas meningkatkan faktor risiko untuk berbagai penyakit, termasuk kanker. ${ }^{1}$ Sebuah meta-analisis menunjukan bahwa berat badan berlebih memiliki risiko lebih tinggi terhadap leukemia. ${ }^{3}$ Obesitas dikaitkan dengan angka insidens leukemia yang lebih tinggi dan prognosis yang buruk. ${ }^{4}$ Adanya obesitas akan memengaruhi insidens kanker dan pengobatannya. ${ }^{5}$ Oleh karena itu, tinjauan pustaka ini hendak membahas obesitas sebagai faktor prognostik pada anak dengan LLA. Tinjauan pustaka ini akan pertama-tama akan sekilas menguraikan faktor risiko, pemeriksaan klinis dan penunjang, maupun tatalaksana LLA, dalam rangka memberikan gambaran tentang faktor-faktor yang turut menentukan prognosis sebelum masuk ke pembahasan yang lebih spesifik pada bahasan tentang obesitas sebagai faktor prognostik.

\section{Faktor Risiko LLA}

LLA menyerang anak dari segala usia, dengan insidens LLA yang memuncak pada usia dua sampai lima tahun, dan sedikit lebih banyak terjadi pada anak laki-laki dibandingkan perempuan dengan rasio $55 \%$ dibanding 45\%. ${ }^{1,6}$ Insidens LLA bervariasi tergantung dari ras dan etnisitas, dengan rentang dari 14,8 kasus per 1.000 .000 anak pada kulit hitam, 35,6 kasus per 1.000 .000 pada kulit putih, dan 40,9 kasus per 1.000 .000 pada kaum hispanik. ${ }^{1,7}$ Beberapa faktor genetik dikaitkan dengan peningkatan risiko terjadinya LLA, misalnya down syndrome. ${ }^{8}$ Studi asosiasi genom telah mengidentifikasi varian polimorfik dari beberapa gen (termasuk ARID5B, CEBPE, GATA3, dan IKZF1) yang diasosiasikan dengan peningkatan risiko LLA. ${ }^{9}$ Peningkatan risiko juga dikaitkan dengan paparan terhadap radiasi dan beberapa zat kimia, namun hal ini hanya terjadi pada sebagian kecil kasus dan perlu ditelaah lebih

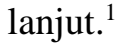

\section{Manifestasi Klinis dan Pemeriksaan Penunjang}

Gejala klinis yang umum ditemukan pada LLA adalah memar dan perdarahan akibatkan oleh trombositopenia, pucat, lelah berkepanjangan disebabkan anemia, dan infeksi yang disebabkan oleh neutropenia. ${ }^{1}$ Infiltrasi leukemik pada hati, limpa, kelenjar getah bening dan mediastinum sangat umum terjadi saat diagnosis ditegakkan. ${ }^{1}$

Tanda klinis yang paling sering menyertai pasien dengan LLA adalah hepatomegali, splenomegali, demam, limfadenopati. ${ }^{2}$ Keterlibatan dari susunan saraf pusat dan adanya massa pada mediastinum masing-masing ditemukan sebesar 6,6\% dan $11,8 \% .^{2}$

Anemia ditemukan pada $85 \%$ dari pasien anak dengan LLA, 35\% di antaranya mengalami anemia berat $(\mathrm{Hb}<7 \mathrm{~g} / \mathrm{dL}) .^{2}$ Pada saat diagnosis, pasien dengan sel T-LLA memiliki kadar $\mathrm{Hb}$ yang lebih tinggi $(10,6 \pm$ 2,45 g/dL) dibandingkan dengan pasien sel BLLA $(7,9 \pm 2,55 \mathrm{~g} / \mathrm{dl}$; nilai $\mathrm{p}=0,011){ }^{2}$ Jumlah trombosit dibawah $100 \times 10^{9} \mathrm{sel} / \mathrm{L}$ ditemukan pada $65 \%$ pasien, dan $10,5 \%$ diantaranya memiliki trombositopeni berat dengan $<20,0 \mathrm{x}$ $10^{9} \mathrm{sel} / \mathrm{L} .^{2}$ Jumlah leukosit rata-rata saat diagnosis adalah $31,8 \pm 53,4 \times 10^{9} \mathrm{sel} / \mathrm{L} .{ }^{2}$

\section{Tatalaksana LLA dan Prognosis Berdasarkan Tatalaksana}

Tatalaksana LLA terdiri atas tatalaksana kuratif dan suportif. Tatalaksana kuratif bertujuan untuk menyembuhkan leukemia berupa kemoterapi yang terdiri atas induksi remisi, intensifikasi/konsolidasi, rumatan (maintenance) serta terapi pada susunan saraf pusat. ${ }^{10,11}$ Protokol kemoterapi saat ini ditentukan berdasarkan klasifikasi risiko. Protokol yang digunakan di Indonesia saat ini yaitu protokol WK-ALL 2000, protokol LLA 2006, protokol LLA 2013, dan protokol nasional (Jakarta). ${ }^{12}$ 
Tahap awal pada tatalaksana kuratif LLA yaitu terapi induksi. Terapi induksi berlangsung dalam 4-6 minggu dengan menggunakan 3-4 obat yang berbeda (deksametason, vinkristin, L-asparaginase dan atau antrasiklin). ${ }^{10-13}$ Respon terapi pada pasien LLA dapat berbedabeda. Beberapa respon terapi LLA antara lain: 10,14

- Remisi komplit, yaitu tidak ditemukan tanda maupun gejala leukemia, sementara jumlah sel blas di bawah 5\% dari sel berinti yang ditemukan pada aspirasi sumsum tulang, jumlah leukosit lebih dari 3000/ $\mathrm{LL}$ dengan hitung jenis leukosit baik, jumlah granulosit di atas $2000 / \mu \mathrm{L}$, hemoglobin di atas $12 \mathrm{~g} / \mathrm{dL}$ tanpa transfusi, jumlah trombosit di atas $100.000 / \mu \mathrm{L}$, serta pemeriksaan cairan serebrospinal normal.

- Refraktori yaitu periode tidak terjadi remisi pada fase pertama pengobatan.

- Progresif, yaitu perburukan penyakit: terjadi peningkatkan jumlah dari sel blas di sumsum tulang, darah maupun jaringan tubuh.

- Relaps, yaitu kembalinya kondisi leukemia yang sebelumnya sudah terjadi remisi. Jumlah sel blas pada sumsum tulang atau darah menjadi banyak atau menyebar ke jaringan tubuh.

Hasil yang diharapkan pada terapi induksi adalah tercapainya perpanjangan remisi dan meningkatkan kesembuhan,sekitar 95\% pasien mencapai kondisi ini. ${ }^{10}$ Pasien yang gagal mencapai remisi sebanyak setengahnya merupakan pasien yang gagal pengobatan (gagal induksi) dan sisanya merupakan pasien yang tidak bertahan dengan pengobatan / meninggal. ${ }^{11}$

Remisi dari kanker yang diinduksi oleh kemoterapi pertama kali diketahui pada tahun $1948 .^{2}$ Sejak saat itu, angka harapan hidup pasien LLA pada anak sudah banyak meningkat dengan berkembangnya serta perbaikan efikasi dari beberapa regimen kemoterapi dan stratifikasi dari intensitas terapi bergantung dari gejala klinis dari pasien, serta perbaikan dari terapi suportif. ${ }^{2}$ Persentase harapan hidup pasien (survival rate) sudah jauh membaik dari $10 \%$ pada tahun 1960 menjadi $90 \%$ pada saat ini. ${ }^{1,2}$ Walaupun pengobatan terkini seperti kemoterapi dan radioterapi menunjukan respons yang cukup baik (lebih dari $80 \%$ mengalami perbaikan), hal ini dapat diperberat dikarenakan meningkatkan risiko terjadinya keganasan sekunder. ${ }^{1}$ Pasien yang mengalami relaps memiliki pilihan terapi yang lebih sedikit. ${ }^{1}$ Imunoterapi menggunakan sel $\mathrm{T}$ yang direkayasa menunjukan perbaikan yang menjanjikan untuk beberapa pasien. ${ }^{6}$ Namun, terapi eksperimental ini menunjukan beberapa toksisitas dan masih membutuhkan penelitian lebih lanjut. ${ }^{6}$

Intensifikasi atau konsolidasi adalah kemoterapi tambahan setelah remisi komplit dan berguna sebagai pencegahan leukemia pada susunan saraf pusat. ${ }^{10}$ Pada pasien dengan risiko sedang dan tinggi, induksi dilakukan secara lebih intensif dengan tujuan untuk memperbaiki kualitas remisi. ${ }^{10,11}$ Terapi ini berlangsung sekitar 6-9 bulan. Pada tahap ini, obat yang dipakai merupakan obat kombinasi dari berbagai agen kemoterapi yang tidak digunakan dalam tahap induksi seperti merkaptopurin, tioguanin, metotreksat, siklofosfamid, etoposid, dan sitarabin. ${ }^{11}$

Terapi rumatan (maintenance) menggunakan obat merkaptopurin setiap hari dan metotreksat sekali semingu secara oral dengan sitostatika lain selama perawatan tahun pertama. ${ }^{10,11}$ Durasi terapi rumatan ini berlangsung sekitar 2-2,5 tahun. Jumlah leukosit dan pemantauan konsentrasi obat selama terapi rumatan digunakan untuk mengatur dosis dari sitostatika. ${ }^{10,11}$

Terdapat beberapa metode untuk terapi LLA pada sistem saraf pusat yaitu pemberian kemoterapi secara intratekal, pemberian kemoterapi sistemik yang dapat menembus sawar darah otak (blood-brain barrier), dan radiasi kranial. ${ }^{11}$ Infus berulang metotreksat dosis sedang $\left(500 \mathrm{mg} / \mathrm{m}^{2}\right)$ atau dosis tinggi (3$5 \mathrm{~g} / \mathrm{m}^{2}$ ) dapat dikombinasi dengan terapi injeksi intratekal dengan metotreksat. ${ }^{10}$ Kemoterapi sistemik yang memiliki efek pada susunan saraf pusat antara lain deksametason, metotreksat dosis tinggi, sitarabin, dan asparaginase.${ }^{11} \mathrm{Pada}$ beberapa pasien risiko tinggi dengan usia $>5$ tahun, mungkin lebih efektif dengan menggunakan radiasi kranial (18-24 Gy) dibandingkan pemakaian kemoterapi sistemik dosis tinggi. ${ }^{10}$ Akan tetapi, karena risiko toksisitas radiasi kranial yang menimbulkan disabilitas intelektual dan neoplasma sekunder, penggunaannya sebagai terapi berkurang. ${ }^{10}$ Banyak protokol pengobatan yang 
menggunakan radiasi kranial hanya pada kasus risiko tinggi terjadinya relaps pada susunan saraf pusat. ${ }^{11}$

Penggunaan transplantasi sumsum tulang atau allogeneic hematopoietic stem cell transplant (HSCT) pada remisi pertama pasien LLA masih menjadi perdebatan. ${ }^{11}$ Pada umumnya, HSCT digunakan pada pasien yang memiliki risiko sangat tinggi untuk terjadinya relaps dan atau gagal pengobatan. ${ }^{11}$

Tatalaksana suportif pada pasien LLA dapat berupa pemberian antibiotik, mengatasi penyakit penyerta lain, pemberian obat untuk meningkatkan granulosit, pemberian anti jamur, dan nutrisi yang baik serta pendekatan melalui segi aspek psikososial. ${ }^{10}$

\section{Obesitas dan LLA}

Penelitian terhadap obesitas pada LLA dapat mengacu pada American Academy of Pediatrics Guideline, obesitas pada anak didefinisikan sebagai indeks massa tubuh lebih dari persentil 95 terhadap usia dan jenis kelamin. ${ }^{15}$ Demikian pula IMT dapat dihitung menggunakan grafik Centers for Disease Control and Prevention untuk anak usia 2 sampai 20 tahun. ${ }^{15}$ Sel adiposit pada pasien obesitas dengan kanker memiliki peran dalam fungsi metabolik, sistem imun, dan fisiologi endokrin yang masing-masing berkontribusi dalam proses karsinogenesis. ${ }^{5,16}$ Obesitas berkaitan dengan peningkatan sitokin proinflamasi (TNF-alfa, acute phase reactant), dan adanya peran adiponektin dalam pembentukan kanker. ${ }^{5,16}$

Penelitian yang dilakukan oleh Sari dkk di Departemen Ilmu Kesehatan Anak FKUI/RSCM pada tahun 2007-2009 menemukan hiperleukositosis pada 6 dari 12 pasien obesitas dengan jumlah leukosit ditemukan berkisar antara 66.700$159.000 / \mathrm{mm}^{3}{ }^{5}$ Jumlah leukosit yang tinggi sering ditemukan pada pasien obesitas dikarenakan adanya pengaruh obesitas terhadap pertumbuhan sel. ${ }^{5}$ Penelitian yang dilakukan oleh Butturini dkk menyimpulkan jumlah leukosit yang tinggi saat pertama kali terdiagnosis merupakan salah satu prediktor hasil akhir yang buruk pada pasien LLA anak. ${ }^{17}$

\section{Prognosis Penderita LLA dengan Obesitas}

Penelitian Sari dkk menyimpulkan pasien obesitas memiliki risiko lebih tinggi untuk mengalami relaps dikarenakan dosis kemoterapi yang diterima tidak adekuat. ${ }^{5}$ Dosis yang digunakan seringkali menjadi lebih kecil jika dihitung berdasarkan luas permukaan tubuh antara pasien obesitas dan non-obesitas. ${ }^{15}$ Pada penelitian yang sama juga didapatkan anak usia 10 tahun atau lebih dengan obesitas memiliki risiko 1,5 kali lebih besar untuk mengalami relaps $(\mathrm{p}=0,013)$ jika dibandingkan dengan anak berusia kurang dari 10 tahun. ${ }^{15}$ Kemungkinan relaps pada LLA anak dan remaja tidak dipengaruhi oleh jenis kelamin. ${ }^{15}$ Pasien anak usia di atas 10 tahun dengan berat badan lebih dari $60 \mathrm{~kg}$ saat diagnosis memiliki risiko lebih tinggi untuk mengalami relaps disertai dengan event-free survival yang rendah. ${ }^{17}$ Penelitian yang dilakukan oleh Sari dkk, mendapatkan 1 dari 2 pasien dengan usia lebih dari 10 tahun yang memiliki berat badan lebih dari $60 \mathrm{~kg}$ mengalami relaps pada fase pemeliharaan, namun meninggal akibat perdarahan intrakranial. ${ }^{5}$

Pada penelitian yang dilakukan oleh Gatot dan Windiastuti pada tahun 2006 yang dikutip oleh Sari dkk, angka relaps pada pasien kelompok risiko tinggi (18,5\%) lebih besar dibandingkan risiko biasa $(17,8 \%) .{ }^{4}$ Penelitian juga menunjukkan risiko relaps pada tahun ketiga pasien obesitas lebih tinggi, yaitu sebesar $30 \% \pm 4 \%$ dibandingkan $20 \% \pm 1 \% \quad(\mathrm{p}=0,01)$ pada pasien non-obes. ${ }^{16}$ Angka harap hidup tahun ketiga pada anak dengan obesitas adalah sebesar $68 \% \pm 5 \%$, dibandingkan $80 \% \pm 1 \%$ $(\mathrm{p}=0,008)$ pada anak yang tanpa obesitas, sedangkan event-free survival tahun ketiga untuk pasien obesitas $63 \% \pm 5 \%$ dibandingkan $74 \% \pm 1 \% \quad(\mathrm{p}=0,001)$ pada anak yang tidak mengalami obesitas. ${ }^{5}$

Pada studi kohort yang dilakukan oleh Gelete dkk, 65 dari 181 pasien memiliki berat badan berlebih/obesitas saat diagnosis. ${ }^{1}$ Tidak ada perbedaan bermakna pada gejala klinis atau hasil laboratorium pasien kecuali angka relaps. ${ }^{4}$ Semua pasien mendapatkan dosis kemoterapi berdasarkan luas permukaan tubuh. ${ }^{1}$ Event free survival lima tahun pada pasien obesitas didapatkan lebih rendah dibandingkan dengan pasien non-obesitas (67\% dibandingkan $81 \%$, dengan $\mathrm{p}=0,03)^{4}$

Pada studi kohort lainnya yang dilakukan oleh Butturini, 343 dari 4260 pasien 
LLA memiliki berat badan berlebih/obesitas. ${ }^{17}$ Walaupun dosis terapi sudah disesuaikan dengan luas permukaan tubuh pasien, hasil akhir dari pasien obesitas didapatkan lebih buruk dibandingkan pasien non-obesitas dan merupakan faktor independen bersamaan dengan usia saat diagnosis, jumlah sel darah putih, ras dan respon sumsum tulang hari ke7. ${ }^{17}$ Ras juga merupakan salah satu faktor prognosis utama yang ditetapkan oleh National Cancer Institute (NCI) dengan angka harapan hidup yang lebih kecil pada yang berkulit hitam dibandingkan putih. ${ }^{18}$

Pada beberapa obat-obatan terutama obat kanker sebagian didistribusikan di jaringan lemak, dosis obat dianjurkan untuk ditentukan berdasarkan Indeks Massa Tubuh (IMT) ditambahkan dengan persentase kelebihan berat badan. $^{19}$ Hal ini sesuai dengan studi farmakokinetik yang dilakukan dimana memperlihatkan bahwa molekul dengan sifat lipofilik ringan atau sedang lebih mudah diprediksi karena distribusi terjadi pada massa otot, sehingga penentuan dosis obat harus didasarkan atas berat badan ideal. ${ }^{19}$ Penurunan dosis relatif L-asparginase sebesar $7 \%$ juga ditemukan pada pasien LLA dengan obesitas dibandingkan dengan non-obesitas. ${ }^{5}$ Perbedaan dosis lebih besar pada pasien usia 10-18 tahun dibandingkan di bawah 10 tahun; hal ini mungkin disebabkan oleh tingginya IMT, sehingga diperlukan dosis yang lebih besar. ${ }^{5,20}$

Obesitas dapat meningkatkan risiko terjadinya LLA terkait beberapa mekanisme, yaitu melalui peningkatan hormon endogen seperti hormon seks steroid, insulin, dan insulin growth factor- $1 .{ }^{5}$ Hal ini disebabkan oleh penumpukan lemak tubuh yang berperan dalam mengontrol pertumbuhan, diferensiasi dan metabolisme sel. $^{5}$ Inflamasi kronik juga berperan dalam timbulnya sel kanker. ${ }^{5}$ Sel adiposit merupakan salah satu sumber yang menimbulkan sitokin inflamasi. ${ }^{5}$ Peningkatan konsentrasi C-Reactive Protein merupakan bentuk respons inflamasi yang berhubungan dengan timbulnya kanker. ${ }^{5}$ Pada pasien obesitas, terjadi peningkatan stres oksidatif dan kerusakan oksidatif yang terjadi pada DNA, yang meningkatkan risiko kanker. $^{5,21}$ Hubungan antara inflamasi kronik dengan kanker pertama kali dideskripsikan oleh Virchow pada tahun $1863 .{ }^{5}$ Peran adiponektin dikaitkan dengan terjadinya kanker melalui protein hasil produksi adiposit yang berperan penting dalam pengaturan sensitivitas insulin dan inflamasi. ${ }^{22}$ Sampai saat ini belum ada bukti maupun jumlah penelitian yang cukup mengenai keterkaitan antara penurunan kadar adiponektin dengan peningkatan leukemia pada anak. ${ }^{5,22}$ Berkurangnya kadar adiponektin berhubungan erat dengan peningkatan jenis kanker tertentu, namun belum terbukti adanya kaitan yang bermakna antara penurunan kadar protein ini dengan peningkatan leukemia pada anak. ${ }^{5,22}$

Faktor lain yang juga dapat menjadi penentu hasil akhir/prognosis pasien dengan LLA adalah usia dan kadar leukosit, terutama pada pre-B LLA (precursor B-cell. ${ }^{23}$ Pasien yang didiagnosis pada usia 1 sampai 10 tahun memiliki hasil akhir yang lebih baik dibandingkan pasien yang didiagnosis pada usia dibawah 1 tahun atau di atas 10 tahun. ${ }^{23}$ LLA pada bayi diketahui memiliki prognosis yang lebih buruk dengan event free survival (EFS) 4 tahun sebesar 47\%.23,24 Kadar leukosit di atas $50.000 / \mathrm{mm}^{3}$ pada saat diagnosis juga dikaitkan dengan hasil akhir yang buruk. ${ }^{23}$ Menurut National Cancer Institute/Rome Criteria, ketiga kriteria tersebut menentukan kategori risiko standar vs. risiko tinggi. ${ }^{23}$ Sebaliknya pada sel T-LLA, usia dan kadar leukosit tidak menjadi acuan hasil akhir dan prognosis. ${ }^{25}$ Respon terhadap terapi diukur dengan cara melihat jumlah bersihan dari blas perifer setelah 1 minggu penggunaan steroid. ${ }^{23}$ Pasien dengan respon terhadap steroid yang baik memiliki jumlah blas perifer dibawah $1000 / \mathrm{mm}^{3}$ memiliki hasil akhir yang lebih baik dibandingkan pasien dengan jumlah blas perifer diatas $1000 / \mathrm{mm}^{3} .23,26$

\section{Penutup}

Anak dengan Leukemia limfoblastik Akut (LLA) yang disertai obesitas memiliki hasil akhir serta prognosis yang lebih buruk. Hal ini diperparah jika terdapat faktor lain seperti usia saat diagnosis di bawah 1 tahun atau lebih dari 10 tahun, jumlah sel darah putih lebih dari $50.000 / \mathrm{mm}^{3}$ saat diagnosis, ras berkulit hitam serta respon pengobatan yang lambat. Dosis terapi perlu disesuaikan dengan luas permukaan tubuh untuk hasil yang optimal. Pendekatan multidisiplin dan kerjasama orang tua/pengasuh pasien sangat diperlukan dalam penanganan anak dengan obesitas. 
1. Hunger SP, Mulighan CG. Acute lymphoblastic leukemia in children. $\mathrm{N}$ Engl J Med. 2015;373(16):1541-52. doi: 10.1056/nejmra1400972

2. Lustosa de Sousa DW, De Almeida Ferreira FV, Cavalcante Fèlix FH, Oliveira MV. Acute lymphoblastic leukemia in children and adolescents: Prognostic factors and analysis of survival. Rev Bras Hematol Hemoter. 2015;37(4):223-9. doi: 10.1016/j.bjhh.2015.03.009

3. Larsson SC, Wolk A. Overweight and obesity and incidence of leukemia: a Meta-analysis of cohort studies. Int $\mathrm{J}$ Cancer. 2008;122:1418-21.

4. Gelelete CB, Pereira SH, Azevedo AMB, Thiago LS, et al. Overweight as a prognostic factor in children with acute lymphoblastic leukemia. Obesity. 2011;19:1908-1911. doi: 10.1038/oby.2011.195

5. Sari TT, Windiastuti E, Cempako GR, Devaera Y. Prognosis leukemia limfoblastik akut pada anak obes. Sari Pediatri. 2010;12(1):58-62.

6. Ntziachristos P. iAMPlified gene expression offers new insights in B cell precursor leukemia subtype. Leukemia \& Lymphoma. 2020:1-3. doi: 10.1080/10428194.2019.1695055

7. Lim JY, Bhatia S, Robinson LL, Yang JJ. Genomics of racial and ethnic disparities in childhood acute lymphoblastic leukemia. Cancer. 2014;120:955-62.

8. Buitenkamp TD, Izraeli S, Zimmermann $\mathrm{M}$, et al. Acute lymphoblastic leukemia in children with down syndrome: A retrospective analysis from the ponte di legno study group. Blood. 2014;123:70-7.

9. Perez-Andreu V, Roberts KG, Harvey RC, et al. Inherited GATA3 variants are associated with ph-like childhood acute lymphoblastic leukemia and risk of relapse. Nat Genet. 2013;45:1494-8.

10. Pernomo B, Sutaryo, Ugrasena I, Windiastuti E, Abdulsalam M. Buku ajar hematologi-onkologi anak. $2^{\text {nd }}$ ed. Jakarta: Ikatan Dokter Anak Indonesia; 2006. 2424.

11. Cooper SL, Brown PA. Treatment of pediatric acute lymphoblastic leukemia.
73.

12. Yakin R, Syarif S, Tehuteru ES. Perbandingan kesintasan tiga tahun pada anak leukemia limfoblastik akut antara protokol pengobatan 2006 dan 2013. Indonesian Journal of Cancer. 2017;6;11(3):111-7.

13. National Cancer Institute. Childhood acute lymphoblastic leukemia treatment $\left(\mathrm{PDQ}{ }^{\circledR}\right)$-health professional version [Internet]. National Cancer Institute. 2020 [cited 2020 Mar 2]. Available from: https://www.cancer.gov/types/leukemia/h p/child-all-treatment-pdq\#_727

14. National Comprehensive Cancer Network. Acute lymphoblastic leukemia [Internet]. NCCN guidelines for patients. 2019 [cited 2020 Mar 2]. Available from: https://www.nccn.org/patients/guidelines/ content/pdf/all-patient.pdf

15. Butturini AM, Dorey FJ, Lange BJ, Henry DW, Gaynon PS, et al. Obesity and outcome in pediatric acute lymphoblastic leukemia. Journal of Clinical Oncology. 2007;25(15):2063-8.

Doi: 10.1200/JCO.2006.07.7792

16. Hong K, Yan E, Chen S, Li Z, Heber D. Obesity and Cancer: Inflammation and molecular pathogenesis. Obesity Manag. 2007;3:115-20.

17. Butturini A, Dorey F, Gaynon P, Fu C, Franklin J, Siegel S, et al. Obesity and body weight independently predict relapse and survival in preadolescents and teenagers with acute lymphoblastic leukemia (ALL): A Retrospective analysis of five children cancer group (CCG) studies. Blood (ASH Annual Meeting Abstracts).2004; 104:Abstract 992.

18. Hunger SP, Lu X, Devidas M, Camitta BM, Gaynon P, Winick NJ, et al. Improved survival for children and adolescents with acute lymphoblastic leukemia between 1990-2005: A report from the children's oncology group. 2012;30(4):1663-8.

Doi: $10.1200 / J C O .2011 .37 .8018$

19. Cheymol G. Effects of obesity on pharmacokinetics implication for drug therapy. Clin Pharmacokinet. 2000;39:215-31.

20. Baillargeon J, Langevin AM, Lewis M, Thomas PJ, Mullins J, Dugan J, et al. Lasparginase as a marker of chemotherapy 
dose modification in children with acute lymphoblastic leukemia. Cancer. 2005;104:2858-61.

21. McMillan DC, Sattar N, Lean M, McArdle CS. Obesity and cancer. BMJ. 2006;333:1109-11.

22. Barb D, Williams CJ, Neuwirth AK, Mantzoros CS. Adiponectin in relation to malignancies: A review of existing basic research and clinic swal evidence. Am J Clin Nutr. 2007;86:858S-66S.

23. Lee JW, Cho B. Prognostic factors and treatment of pediatric acute lymphoblastic leukemia. Korean J Pediatr. 2017;60(5):129-37. doi: 10.3345/kjp.2017.60.5.129

24. Pieters R, Schrappe M, De Lorenzo P, Hann I, De Rossi G, Felice M, et al. A Treatment protocol for infants younger than 1 year with acute lymphoblastic leukemia (Interfant-99): an observational study and a multicentre randomised trial. Lancet. 2007;370:240-50.

25. Smith M, Arthur D, Camitta B, Carroll AJ, Crist W, Gaynon P, et al. Uniform approach to risk classification and treatment assignment for children with acute lymphoblastic leukemia. J Clin Oncol. 1996;14:18-24.

26. Moricke A, Zimmermann M, Reiter A, Henze G, Schrauder A, Gadner H, et al. Long term results of five consecutive trials in childhood acute lymphoblastic leukemia performed by the ALL-BFM study group from 1981-2000. Leukemia. 2010;24:265-84. 